\title{
PENGARUH TEMPERATUR KALSINASI OPTIMUM TERHADAP PEMBENTUKAN KALSIUM OKSIDA DARI CANGKANG TELUR BEBEK SEBAGAI KATALIS PADA SINTESIS MINYAK KELAPA MENJADI BIODIESEL
}

\author{
Vira Valasara $^{1}$, Sri Rezeki ${ }^{1}$, Syahrul Khairi ${ }^{1}$ \\ ${ }^{1}$ Jurusan Teknik Kimia, Universitas Tanjungpura, Pontianak \\ Email Korespondensi: viravalasara@gmail.com
}

\begin{abstract}
Abstrak
Cadangan minyak bumi dunia semakin lama semakin berkurang, sehingga perlu energi alternatif untuk menggantikan posisi minyak bumi, di antaranya adalah penggunaan biodiesel. Biodiesel dapat diproduksi dari berbagai macam minyak nabati, salah satunya minyak kelapa. Pembuatan biodiesel memerlukan katalis, katalis yang banyak dikembangkan saat ini adalah katalis heterogen $\mathrm{CaO}$. CaO dapat diperoleh dari $\mathrm{CaCO}_{3}$ yang dikalsinasi. Salah satu sumber yang mengandung $\mathrm{CaCO}_{3}$ yang tinggi adalah cangkang telur bebek. Penelitian ini bertujuan untuk mengetahui pengaruh variasi suhu kalisnasi cangkang telur bebek pada 700,800, 900 dan $1000^{\circ} \mathrm{C}$ terhadap katalis $\mathrm{CaO}$ yang dihasilkan dan pengaruh terhadap pembentukan biodiesel menggunakan minyak kelapa. Pada penelitian ini kalsinasi cangkang telur bebek dilakukan selama 4 jam. Proses transesterifikasi dengan suhu reaksi $60^{\circ} \mathrm{C}$ menggunakan metanol dan minyak kelapa dengan perbandingan mol 9:1 selama 4 jam. Kosentrasi katalis $\mathrm{CaO}$ yang digunakan yaitu 3,5\%(b/b). Katalis diuji tingkat kristalinitas dengan analisis XRD. Metil ester dianalisa dengan GCMS, untuk standar kualitas biodiesel parameter yang diuji yaitu densitas, viskositas, angka setana, dan residu karbon. Pembentukan optimum $\mathrm{CaO}$ pada proses kalsinasi adalah pada suhu $900^{\circ} \mathrm{C}$. Reaksi transesterifikasi yang dilakukan menghasilkan yield sebesar $92,12 \%$. Biodiesel yang dihasilkan mempunyai nilai densitas $859 \mathrm{~kg} / \mathrm{m}^{3}$, viskositas kinematik 11,6 $\mathrm{mm}^{2} / \mathrm{s}$, angka setana 55,7 dan residu karbon $0,37 \%(\mathrm{~b} / \mathrm{b})$.
\end{abstract}

$\underline{10.26418 / \text { pipt.2021.24 }}$

Kata kunci: biodiesel, $\mathrm{CaO}$, cangkang telur bebek, minyak kelapa

\section{PENDAHULUAN}

Permintaan Bahan Bakar Minyak di Indonesia semakin meningkat, baik itu untuk keperluan industri, transportasi maupun rumah tangga. Menurut data dari Kementrian ESDM semakin tahun konsumsi semakin meningkat sedangkan ketersediannya sendiri semakin menipis. Sejalan dengan hal itu pemerintah mengeluarkan peraturan mandatori B30 dimana mengharuskan penggunaan biodiesel untuk sektor bersubsidi dan sektor nonsubsidi. B30 merupakan jenis bahan bakar hasil pencampuran minyak solar dengan biodiesel berbahan dasar minyak nabati sebanyak 30 persen.

Sumber energi yang dapat digunakan untuk pembuatan biodiesel salah satunya adalah minyak nabati. Minyak nabati yang dapat diubah menjadi bahan bakar adalah minyak kelapa. Menurut Kementerian Perindustrian (2014), area perkebunan kelapa di Indonesia menduduki peringkat pertama di dunia yaitu dengan luas 3,88 juta hektar yang memproduksi 3,2 juta ton. Rendemen kelapa untuk diolah menjadi biodiesel sebesar 2689 biodiesel/ha.

Minyak kelapa terdiri dari satu unit gliserin dan tiga unit asam lemak yang dapat diubah menjadi senyawa ester. Apabila minyak kelapa direaksikan dengan metanol akan menghasilkan Coco Methyl Esther (Coco Biodiesel). Biodiesel disintesis dari minyak melalui reaksi transesterifikasi dengan menggunakan katalis. Katalis pembuatan biodiesel biasanya berupa katalis homogen dan katalis heterogen. Salah satu jenis katalis heterogen yang banyak dikembangkan saat ini adalah $\mathrm{CaO} . \mathrm{CaO}$ dapat diperoleh dari $\mathrm{CaCO}_{3}$ yang banyak terdapat di cangkang kerang, cangkang telur dan tulang hewan. Sintesis katalis $\mathrm{CaO}$ dari limbah sebagai bahan baku sedang dikembangkan. Penggunaan limbah ini bisa 
mengurangi dan mendaur ulang sampah yang sudah tidak terpakai lagi.

Pada penelitian ini katalis heterogen yang akan digunakan berasal dari cangkang telur yaitu cangkang telur bebek. Pembentukan $\mathrm{CaO}$ dari $\mathrm{CaCO}_{3}$ dengan proses kalsinasi memerlukan optimasi suhu kalsinasi agar dapat diperoleh konversi yang maksimal dengan suhu optimum. Oleh karena itu, penelitian ini dilakukan untuk menguji pengaruh suhu kalsinasi terhadap $\mathrm{CaO}$ yang terbentuk dari cangkang telur bebek sebagai katalis pada reaksi transesterifikasi minyak kelapa dan menguji karakteristik biodiesel yang dihasilkan.

\section{METODOLOGI}

\section{Tahap Proses Kalsinasi Cangkang Telur Bebek $\left(\mathrm{CaCO}_{3}\right)$}

Cangkang telur bebek dibersihkan dari debu dan kotoran kemudian dikeringkan di dalam oven dengan suhu $100^{\circ} \mathrm{C}$ selama 3 jam untuk mengurangi kadar air dalam cangkang. Setelah itu, dilakukan proses pengecilan ukuran partikel, lalu disaring lolos ayakan 80 mesh. Selanjutnya dikalsinasi dalam furnace dengan temperatur $700,800,900$ dan $1000^{\circ} \mathrm{C}$ selama 4 jam hingga menjadi abu. Setelah itu abu hasil kalsinasi ditimbang dan dihitung yield dan persen dekomposisinya. Cangkang telur bebek yang telah dikalsinasi kemudian dianalisis menggunakan mesin XRD-3550 dengan tegangan $30 \mathrm{~mA}$ dan $40 \mathrm{kV}$, radiasi $\mathrm{Cu}(\mathrm{L}=1.54060 \AA)$ sudut operasi $2 \theta 10^{\circ}$ $100^{\circ}$, scan step $0,010^{\circ}$ dan waktu 8,26 detik.

\section{Proses Tranesterifikasi Minyak Kelapa Menggunakan Katalis Cangkang Telur Bebek}

Proses transesterifikasi ini menggunakan katalis cangkang telur bebek $(\mathrm{CaO})$ sebanyak 3,5\% (b/b), dimana pertama $\mathrm{CaO}$ dicampurkan dengan metanol yang telah dihitung terlebih dahulu hingga sesuai dengan rasio molar metanol/minyak kelapa 9:1 lalu dipanaskan selama 5 menit dengan suhu $40^{\circ} \mathrm{C}$. Setelah itu, dimasukkan minyak kelapa sebanyak 100 gram. Campuran minyak kelapa, metanol dan katalis dipanaskan hingga mencapai suhu konstan yaitu $60^{\circ} \mathrm{C}$, campuran dihomogenkan menggunakan magnetic stirrer dengan selama 4 jam dan dijaga suhu nya tetap konstan. Metil ester campuran reaksi yang dihasilkan dipisahkan dengan katalis $\mathrm{CaO}$ dan dicuci untuk memisahkan lapisan bawah yang terbentuk merupakan campuran sisa $\mathrm{CaO}$, metanol, gliserol dan trigliserida yang tidak bereaksi. Perlakuan ini diulang beberapa kali hingga air cucian berwarna bening dan $\mathrm{pH}$ air pencucian menjadi netral. Lapisan atas yang terbentuk merupakan metil ester. Metil ester kemudian ditimbang dan dihitung yield. Setelah itu metil ester dianalisis dengan GCMS. Metil ester juga dilakukan uji densitas, viskositas, angka setana dan residu karbon biodiesel.

\section{HASIL DAN PEMBAHASAN}

\section{Karakteristik Katalis Cangkang Telur Bebek}

Hasil dekomposisi termal $\mathrm{CaCO}_{3}$ sebagai yield dan \% kehilangan berat dari 4 kali dekomposisi terhadap serbuk cangkang telur bebek secara terpisah ditampilkan pada Gambar 1.

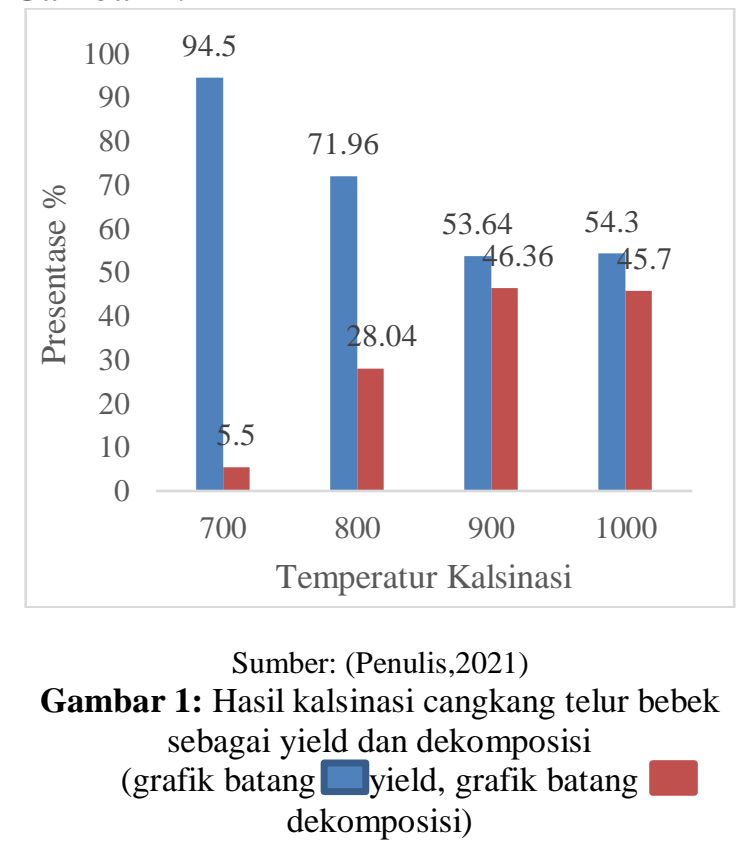


Penurunan massa pada sampel dikarenakan pada proses kalsinasi terjadi pelepasan dari unsur pengisi. Penurunan massa dihitung dari perubahan massa akhir sampel terhadap massa awal sampel karena massa yang hilang berupa gas $\mathrm{CO}_{2}$ (Lesbani, 2013).

Dekomposisi yang terjadi di bawah suhu $600^{\circ} \mathrm{C}$ merupakan tahap awal terjadinya penguapan air pada permukaan padatan dan pelepasan senyawa organik penyusun cangkang keong mas (Correia, 2014). Dekomposisi lanjutan pada rentang suhu $700^{\circ} \mathrm{C}$ sampai $800^{\circ} \mathrm{C}$ terjadi penurunan massa yang tajam dimana mengindikasikan adanya pelepasan signifikan senyawa $\mathrm{CO}_{2}$. Menurut Singh dan Singh (2005), penurunan berat sampel mungkin disebabkan oleh dekomposisi $\mathrm{CaCO}_{3}$ melalui hilangnya karbon dioksida $\left(\mathrm{CO}_{2}\right)$, dan pembentukan kalsium oksida $(\mathrm{CaO})$. Hubungan kuantitas teoritis pada dekomposisi $\mathrm{CaCO}$ ditunjukkan pada persamaan berikut: Panas

$$
\mathrm{CaCO}_{3} \rightarrow \mathrm{CaO}+\mathrm{CO}_{2}
$$

Berdasarkan persamaan tersebut, $1 \mathrm{~mol}$ $\mathrm{CaCO}_{3}$ akan terdekomposisi menjadi $1 \mathrm{~mol}$ $\mathrm{CaO}$ dan 1 mol gas $\mathrm{CO}_{2}$. Asumsi kadar $\mathrm{CaCO}_{3}$ dalam cangkang telur $94 \%$ basis kering (Stadelman, 2000) membentuk $\mathrm{CaO}$ dengan yield maksimum yaitu $52,70 \%$ sedangkan penelitian ini menghasilkan yield kalsinasi maksimum sebesar $53,67 \%$ pasca kalsinasi suhu $900^{\circ} \mathrm{C}$. Sedangkan dekomposisi maksimum terjadi suhu $900^{\circ} \mathrm{C}$ selama 4 jam sebanyak 46,36\%. Hasil penelitian ini menunjukkan kesamaan seperti penelitian yang dilakukan oleh Prastyo (2011), dengan dekomposisi maksimum pada kalsinasi $900^{\circ} \mathrm{C}$ selama 3 jam yaitu sebesar $46 \%$ berat.

Analisa XRD pada katalis bertujuan untuk mengetahui adanya senyawa $\mathrm{CaCO}_{3}$ dan $\mathrm{CaO}$ secara kualitatif. Hasil karakterisasi dengan XRD terhadap cangkang telur bebek dan cangkang telur bebek yang telah dikalsinasi pada suhu 700, 800,900 dan $1000^{\circ} \mathrm{C}$ selama 4 jam ditampilkan sebagai spektra difraksi pada Gambar 2.

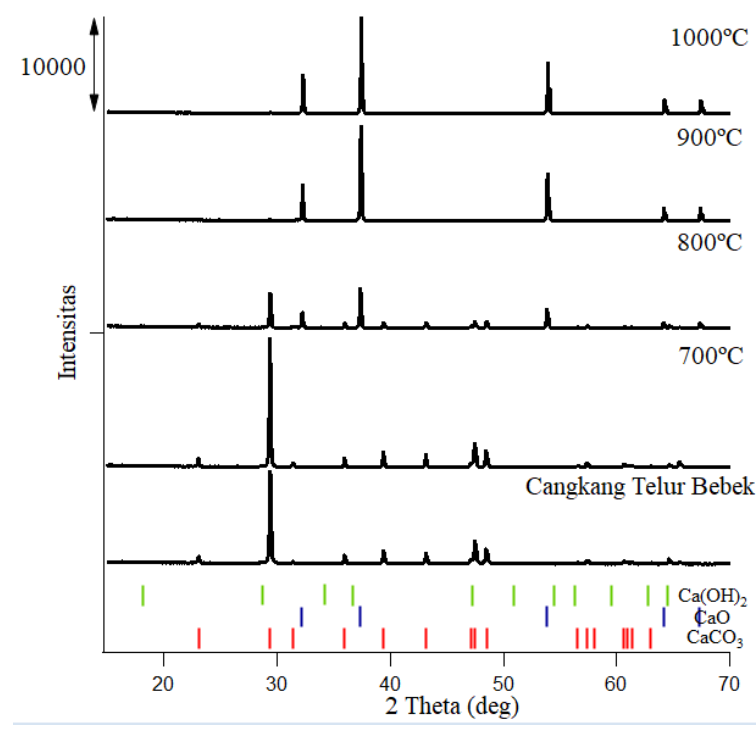

Sumber: (Penulis, 2021)

Gambar 2: Pola difraksi XRD serbuk cangkang telur bebek sebelum kalsinasi; dan setelah kalsinasi

Hasil XRD secara umum menunjukkan komposisi katalis cangkang telur bebek terdiri dari $\mathrm{CaCO}_{3}, \mathrm{CaO}$ dan $\mathrm{Ca}(\mathrm{OH})_{2}$. Dari difraktogram XRD, puncak yang dihasilkan masing-masing dicocokkan dengan puncak ICSD (Inorganic Crystal Structure Database) sebagai pembanding.

Pada pola difraksi menunjukkan bahwa cangkang telur bebek sebagian besar tersusun dari senyawa $\mathrm{CaCO}_{3}$ dengan munculnya puncak pada daerah sudut $2 \theta=$ $29,39^{\circ}, 39,42^{\circ}, 43,18^{\circ}, 47,46^{\circ}$, dan $48,53^{\circ}$ yang dikonfirmasi sesuai dengan standar $\mathrm{CaCO}_{3}$ (ICDD 01-078-4614) sesuai dengan penelitian Stadelman (2000) yang menyatakan cangkang telur bebek mengandung $\mathrm{CaCO}_{3}$. Pada suhu kalsinasi $700^{\circ} \mathrm{C}$ selama 4 jam ditemukan puncak tertinggi didaerah puncak standar $\mathrm{CaCO}_{3}$ calcite seperti yang ditemukan sebelum kalsinasi. Kalsinasi suhu $700^{\circ} \mathrm{C}$ belum mendekomposisi $\mathrm{CaCO}_{3}$ menjadi $\mathrm{CaO}$. Hasil ini sesuai dengan penelitian dari Mohadi (2013) dimana pada suhu $700^{\circ} \mathrm{C}$ puncak yang melebar mengidentifikasikan bahwa pada suhu kalsinasi tersebut belum terbentuk $\mathrm{CaO}$ melainkan masih berupa unsur $\mathrm{Ca}$ dengan struktur semi amorf. Kenaikan temperatur kalsinasi pada suhu 
$800^{\circ} \mathrm{C}$ masih menunjukkan puncak identifikasi senyawa $\mathrm{CaCO}_{3}$ dan juga menunjukkan puncak dan intensitas tertinggi yang mengidentifikasikan senyawa $\mathrm{CaO}$ kristalin. Hasil difraktogram dalam penelitian ini menunjukkan kesamaan dengan penelitian Wei (2009) yang melaporkan pembentukan $\mathrm{CaO}$ dimulai pada suhu $800^{\circ} \mathrm{C}$. Senyawa $\mathrm{CaO}$ terbentuk karena lepasnya senyawa $\mathrm{CO}_{2}$ dari $\mathrm{CaCO}_{3}$ pada suhu yang tinggi. Selain itu senyawa $\mathrm{Ca}(\mathrm{OH})_{2}$ juga teridentifikasi dengan munculnya puncak pada sudut $2 \theta=18,13^{\circ}$, $34,12^{\circ}$, dan $50,9^{\circ}$ sesuai dengan standar $\mathrm{Ca}(\mathrm{OH})_{2}$ (ICDD 01-072-0156) dengan intensitas yang rendah. Berdasarkan penelitian Kouzu (2012) senyawa $\mathrm{Ca}(\mathrm{OH})_{2}$ yang terbentuk dipengaruhi oleh terbentuknya senyawa $\mathrm{CaO}$, dimana $\mathrm{Ca}(\mathrm{OH})_{2}$ terbentuk karena $\mathrm{CaO}$ mempunyai sifat basa kuat akibat keberadaan anion oksigen pada permukaannya.

Penggunaan suhu kalsinasi $900^{\circ} \mathrm{C}$ dan $1000^{\circ} \mathrm{C}$ selama 4 jam telah mampu menunjukkan puncak tertinggi dan tajam, dimana secara stabil yang mengidentifikasikan peningkatan kristalinitas $\mathrm{CaO}$ yang dihasilkan (Mohadi, 2013). Puncak karakteristik $\mathrm{CaO}$ suhu kalsinasi $900^{\circ} \mathrm{C}$ muncul didaerah sudut $2 \theta=$ $32,23^{\circ}, 37,38^{\circ}, 53,9^{\circ}, 64,21^{\circ}$, dan $67,43^{\circ}$ (ICDD 00-004-0777) dan puncak $\mathrm{CaO}$ pada suhu kalsinasi $1000^{\circ} \mathrm{C}$ muncul didaerah sudut $2 \theta=32,28^{\circ}, 37,45^{\circ}, 53,97^{\circ}, 64,28^{\circ}$, dan 67,50 (ICDD 00-004-0777). Puncakpuncak yang terbentuk ini menunjukkan bahwa pada suhu $900^{\circ} \mathrm{C}$ dan $1000^{\circ} \mathrm{C}$ sebagian besar $\mathrm{CaCO}_{3}$ dapat terkonversi menjadi senyawa $\mathrm{CaO}$. Selain itu teridentifikasi juga senyawa $\mathrm{CaCO}_{3}$ dan $\mathrm{Ca}(\mathrm{OH})_{2}$, namun dengan intensitas yang sangat rendah. Hal ini sesuai dengan penelitian Fhadilah (2015) dimana terbentuknya mineral $\mathrm{Ca}(\mathrm{OH})_{2}$ terjadi dikarenakan serbuk $\mathrm{CaO}$ yang terbentuk dari hasil kalsinasi mengalami kontak dengan udara sehingga menyebabkan reaksi hidroksilasi antara air dan fasa $\mathrm{CaO}$. Senyawa $\mathrm{CaO}$ setelah proses kalsinasi akan bersifat higroskopis dan menyebabkan $\mathrm{CaO}$ dengan mudah menyerap uap air dari udara sewaktu dikeluarkan dari tanur. Sedangkan identifikasi senyawa $\mathrm{CaCO}_{3}$ pada suhu $900^{\circ} \mathrm{C}$ dan $1000^{\circ} \mathrm{C}$ dalam penelitian ini menunjukkan kesamaan dengan laporan Zuhra (2015) dimana senyawa $\mathrm{CaCO}_{3}$ masih tersisa, namun dengan intensitas yang sangat rendah. Hal ini dapat disebabkan oleh proses dekomposisi yang tidak merata pada sampel.

Ukuran kristal dapat dihitung dengan menggunakan persamaan Debye Schrerrer dengan nilai intensitas, panjang gelombang, FWHM dan $2 \theta$ yang telah didapatkan dari hasil uji XRD. Berdasarkan persamaan Debye Schrerrer.

$$
D=\frac{K \times \lambda}{\beta \operatorname{Cos} \theta}
$$

Berdasarkan persamaan Debye Schrerrer ini diperoleh ukuran kristal cangkang telur bebek sebelum dan sesudah kalsinasi, ukuran kristal yang diperoleh seperti yang tertera pada Tabel 1 .

Tabel 1: Ukuran kristal cangkang telur bebek sebelum dan sesudah kalsinasi

\begin{tabular}{|l|r|}
\hline \multicolumn{1}{|c|}{ Sampel Data } & D (nm) \\
\hline Cangkang Telur Bebek & 24,688 \\
\hline $700^{\circ} \mathrm{C}$ & 24,877 \\
\hline $800^{\circ} \mathrm{C}$ & 24,218 \\
\hline $900^{\circ} \mathrm{C}$ & 22,826 \\
\hline $1000^{\circ} \mathrm{C}$ & 22,025 \\
\hline
\end{tabular}

Sumber: (Penulis,2021)

Ukuran kristal yang diperoleh dari persamaan Debye Schrerrer setelah kalsinasi mengalami penurunan atau pengecilan. Hasil penelitian ini menunjukkan kesamaan seperti penelitian yang dilakukan oleh Huang (2007) dimana suhu kalsinasi mempengaruhi ukuran kristal dan semakin tinggi suhu dari kalsinasi maka semakin kecil ukuran dari kristal yang dihasilkan. Ukuran partikel berada pada kisaran 24,877 $\mathrm{nm}-22,025 \mathrm{~nm}$ menandakan bahwa partikel tergolong dalam nanomaterial. Semakin kecil ukuran partikel maka semakin luas permukaan partikel sehingga meningkatkan 
kerja dari katalis. Luas permukaan partikel yang semakin besar menyebabkan kontak antara katalis dan reaktan semakin sempurna (Husin, 2011).

Analisa secara semi-kuantitatif untuk mengidentifikasi senyawa secara spesifik, selanjutnya dihitung menggunakan metode RIR (Reference Intensity Ratio) menggunakan data XRD. Komposisi penyusun pada cangkang telur bebek sebelum dan sesudah kalisinasi ditunjukkan pada Tabel 2 .

Tabel 2: Komposisi cangkang telur bebek sebelum dan sesudah kalsinasi

\begin{tabular}{|l|l|l|r|r|r|}
\hline Sampel Data & Senyawa & Fasa & Intensitas & RIR & \% \\
\hline $\begin{array}{l}\text { Cangkang } \\
\text { Telur Bebek }\end{array}$ & $\mathrm{CaCO}_{3}$ & Calcite & 100 & 3,13 & 100 \\
\hline $700^{\circ} \mathrm{C}$ & $\mathrm{CaCO}_{3}$ & Calcite & 100 & 3,13 & 100 \\
\hline $800^{\circ} \mathrm{C}$ & $\mathrm{CaCO}_{3}$ & Calcite & 88,45 & 3,13 & 38,35 \\
\cline { 2 - 6 } & $\mathrm{CaO}$ & Lime & 100 & 4,4 & 60,96 \\
\cline { 2 - 6 } & $\mathrm{Ca}(\mathrm{OH})_{2}$ & Portlandite & 1,43 & 3,48 & 0,69 \\
\hline $900^{\circ} \mathrm{C}$ & $\mathrm{CaCO} 3$ & Calcite & 0,83 & 3,13 & 0,59 \\
\cline { 2 - 6 } & $\mathrm{CaO}$ & Lime & 100 & 4,4 & 99,19 \\
\cline { 2 - 6 } & $\mathrm{Ca}(\mathrm{OH})_{2}$ & Portlandite & 0,29 & 3,48 & 0,23 \\
\hline \multirow{3}{*}{$1000^{\circ} \mathrm{C}$} & $\mathrm{CaCO}$ & Calcite & 1,3 & 3,13 & 0,91 \\
\cline { 2 - 6 } & $\mathrm{CaO}$ & Lime & 100 & 4,4 & 98,33 \\
\cline { 2 - 6 } & $\mathrm{Ca}(\mathrm{OH})_{2}$ & Portlandite & 0,98 & 3,48 & 0,76 \\
\hline
\end{tabular}

Sumber: (Penulis,2021)

Metode ini menentukan komposisi senyawa berdasarkan mineral dengan intensitas tertinggi yang terdeteksi di XRD dan tidak termasuk senyawa penyusun seperti air dan senyawa organik (Ramos, 2011). Pada Tabel 5.3 menunjukkan komposisi penyusun cangkang telur bebek sebelum kalsinasi dan setelah kalsinasi pada suhu $700^{\circ} \mathrm{C}$ adalah $\mathrm{CaCO}_{3}$ dengan fasa calcite. Suhu kalsinasi $800^{\circ} \mathrm{C}$ mempunyai komposisi yang paling tinggi adalah $\mathrm{CaO}$ sebesar $60,96 \%$ yang menunjukkan pembentukan $\mathrm{CaO}$ pada suhu ini sudah melebihi setengah dari $\mathrm{CaCO}_{3}$. Sedangkan pada suhu kalsinasi $900^{\circ} \mathrm{C}$ dan $1000^{\circ} \mathrm{C}$ mempunyai komposisi $\mathrm{CaO}$ melebihi $90 \%$, dan masih terdeteksi senyawa $\mathrm{CaCO}_{3}$ yang belum terdekomposisi menjadi $\mathrm{CaO}$. Selain itu juga terdeteksi senyawa minoritas yaitu $\mathrm{Ca}(\mathrm{OH})_{2}$ di bawah $1 \%$.

Menurut Husin (2011) kristalinitas senyawa akan terus meningkat dengan kenaikan suhu kalsinasi sampai kristal terbentuk secara sempurna. Kalsinasi pada suhu $900^{\circ} \mathrm{C}$ dibandingkan dengan suhu kalsinasi $1000^{\circ} \mathrm{C}$ sudah membentuk kristal $\mathrm{CaO}$ optimal dengan penggunaan energi yang lebih rendah. Oleh karena itu sampel yang akan digunakan untuk reaksi transesterifikasi adalah sampel dengan suhu kalsinasi $900^{\circ} \mathrm{C}$, dimana senyawa $\mathrm{CaO}$ sudah optimum terbentuk sebesar 99,19\% dan memiliki komposisi senyawa lainnya yang paling rendah sekitar $0,59 \%$ untuk $\mathrm{CaCO}_{3}$ serta $0,23 \%$ untuk $\mathrm{Ca}(\mathrm{OH})_{2}$.

\section{Reaksi Transesterifikasi}

Reaksi transesterifikasi minyak dan metanol serta $\mathrm{CaO}$ sebagai katalis untuk reaksi pembentukan biodiesel mekanismenya sebagai berikut: 


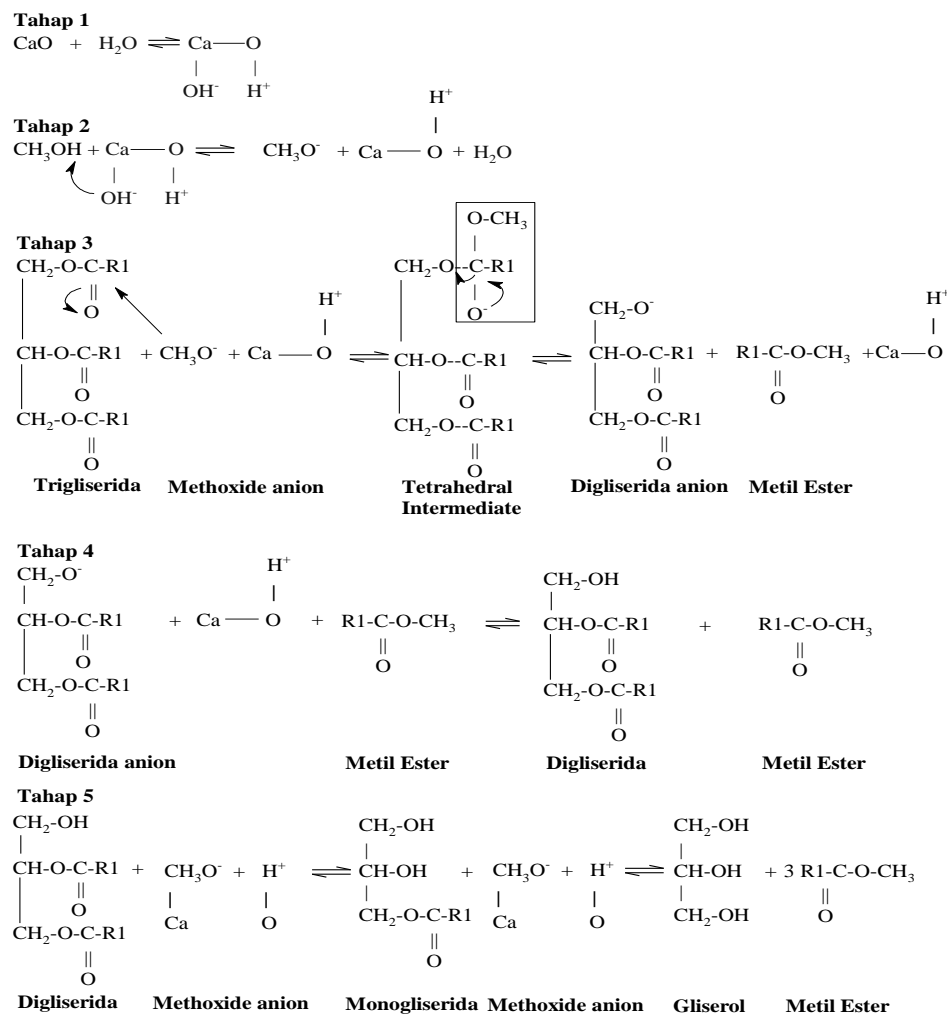

Sumber: (Cristina, 2012; Rahman, 2018)

Gambar 3: Mekanisme Reaksi Transesterifikasi

Tahap 1 terjadi reaksi $\mathrm{CaO}$ dan air, dimana $\mathrm{O}^{2-}$ dari $\mathrm{CaO}$ bereaksi dengan $\mathrm{H}^{+}$ dari air membentuk $\mathrm{OH}^{-}$. Tahap 2 ion hidroksida $\left(\mathrm{OH}^{-}\right)$dari reaksi $\mathrm{CaO}$ dn air mengekstrak proton dari metanol $\left(\mathrm{CH}_{3} \mathrm{OH}\right)$ dan ion hidroksida bereaksi membentuk metoksida anion. Tahap 3 trigliserida bereaksi dengan metoksida anion dimana karbonil karbon trigliserida diserang oleh metoksida anion, kemudian membentuk senyawa antara atau intermediate yang berbentuk tetrahedral. Tahap ini terjadi dengan penataan ulang molekul intermediate untuk membentuk senyawa metil ester dan digliserida anion. Tahap $4 \mathrm{H}^{+}$dari hasil pecahnya metoksida anion bereaksi dengan ion $\mathrm{O}^{-}$dari digliserida anion sehinnga membentuk digliserida. Tahap 5 metoksida anion menyerang

Karbon karbonil yang lain dalam digliserida dan membentuk mono gliserida dan satu mol metil ester. Tahap ini berlanjut hingga dalam reaksi terbentuk tiga mol metil ester dan satu mol gliserol.

Reaksi transesterifikasi pada penelitian ini menghasilkan yield sebesar 92,12\%. Penemuan dalam penelitian ini sesuai dengan penelitian yang dilakukan oleh Achanai (2013), dimana yield biodiesel yang dihasilkan dari minyak sawit dengan katalis cangkang telur bebek $20 \mathrm{wt} \%(\mathrm{~b} / \mathrm{b})$ sebesar 92\%. Metil Ester hasil reaksi transesterifikasi dianalisis menggunakan GC (Gas Chromatography). Instrumen yang digunakan bertujuan untuk mengidentifikasi komposisi senyawa dalam sampel berdasarkan fragmentasi dan kelimpahan dari molekul yang terbentuk. Berikut merupakan komposisi metil ester hasil analisis GC. 


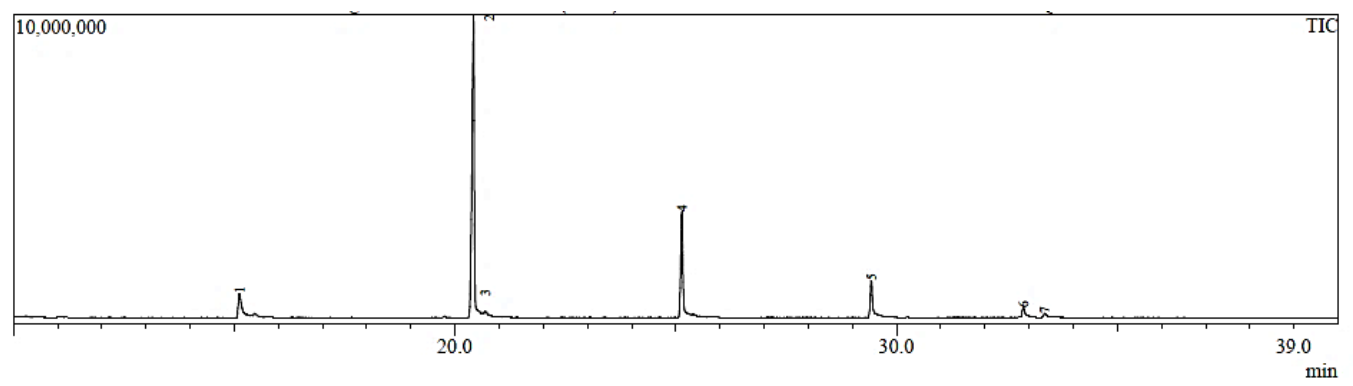

\begin{tabular}{|c|c|c|c|c|c|c|c|c|c|}
\hline & & & & \multicolumn{6}{|c|}{ Peak Report TIC } \\
\hline Peak= & RTime & I. Time & F.Time & Area & Area $\%$ & Height & Height $\%$ & $\mathrm{~A} / \mathrm{H}$ & Mark \\
\hline 1 & 15.118 & 15.050 & 15.250 & 3529668 & 6.33 & 760691 & 4.87 & 4.64 & \\
\hline 2 & 20.418 & 20.308 & 20.508 & 35270681 & 63.26 & 9797282 & 62.73 & 3.60 & \\
\hline 3 & 20.684 & 20.625 & 20.775 & 343827 & 0.62 & 94300 & 0.60 & 3.68 & MI \\
\hline 4 & 25.139 & 25.058 & 25.242 & 11371019 & 20.40 & 3421887 & 21.91 & 3.32 & \\
\hline 5 & 29.427 & 29.358 & 29.525 & 3805969 & 6.83 & 1153895 & 7.39 & 3.29 & \\
\hline 6 & 32.873 & 32.817 & 32.950 & 1075401 & 1.93 & 291309 & 1.87 & 3.69 & \\
\hline 7 & 33.357 & 33.300 & 33.417 & $\begin{array}{r}355793 \\
55752358\end{array}$ & $\begin{array}{r}0.64 \\
100.00\end{array}$ & $\begin{array}{r}99751 \\
15619115\end{array}$ & $\begin{array}{r}0.64 \\
100.00\end{array}$ & 3.53 & MI \\
\hline
\end{tabular}

Sumber: (Penulis, 2021)

Gambar 4: Kromatogram senyawa metil ester menggunakan katalis $\mathrm{CaO}$

Hasil pengukuran Analisa GC menunjukkan tujuh puncak yang mengidentifikasikan 7 senyawa. Senyawa yang memiliki puncak paling tinggi yaitu senyawa ke $2(\mathrm{Rt}=20,418)$ yang memiliki luas daerah $63,26 \%$. Sedangkan luas puncak komponen yang paling rendah ditunjukkan pada puncak ketiga $(\mathrm{Rt}=20,684)$ dengan luas area sebesar $0,62 \%$. Senyawa metil ester dapat diketahui berdasarkan
Fragmentasi yang dapat dilihat pada beberapa spektrum MS. Kromatogram penelitian ini menghasilkan puncak tertinggi yang merupakan metil laurat. Hal ini sesuai dengan penelitian sebelumnya yang dilakukan oleh Satria dan Salahudin (2016) dimana puncak tertinggi metil ester dari minyak kelapa adalah metil laurat dengan luas daerah $63,18 \%$ dan spektrum MS nya dapat dilihat pada Gambar 5.

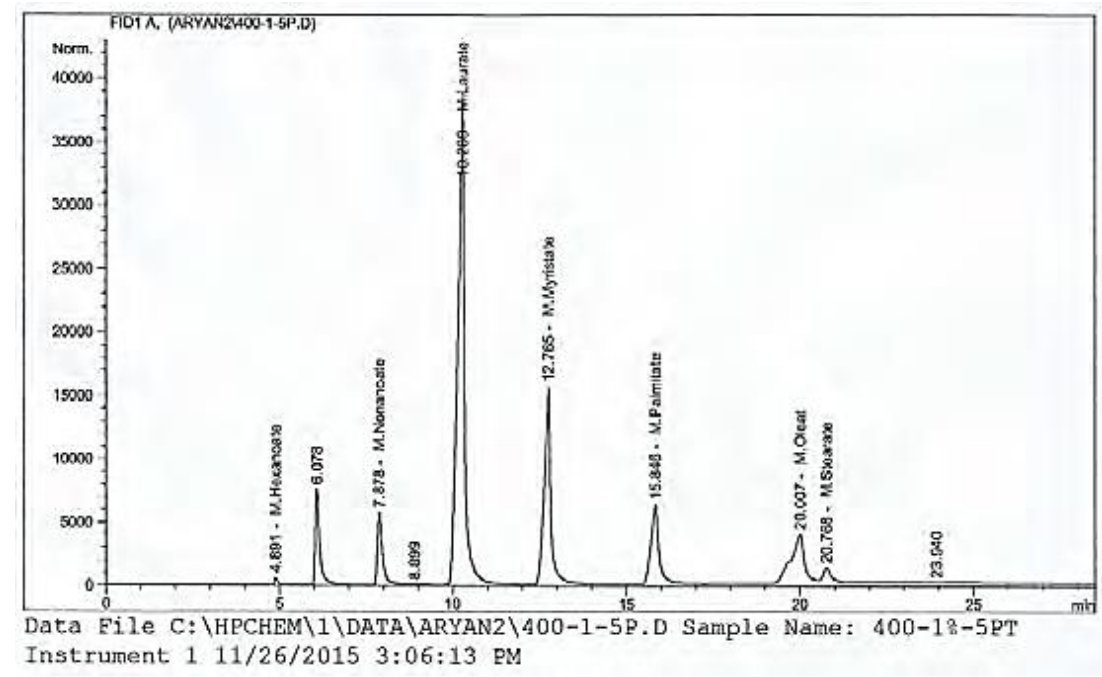

Sumber: (Penulis,2021)

Gambar 5: Kromatogram senyawa metil ester minyak kelapa menggunaka katalis $\mathrm{NaOH}$

Gambar 6 merupakan spetra massa komponen dari peak 1 dengan $\mathrm{Rt}=15,118$ menit memberikan puncak-puncak dengan m/z sebagai berikut: $186,155,143,129$, 115, 101, 87, 74, 59, 57, dan 41. Berdasarkan literatur data spektrum spetra 
massa menunjukkan bahwa komponen pada $\mathrm{Rt}=15,118$ adalah senyawa metil kaprat (metil dekanoat). Mekanisme dari pola fragmentasi senyawa selengkapnya dapat dilihat pada Gambar 7.

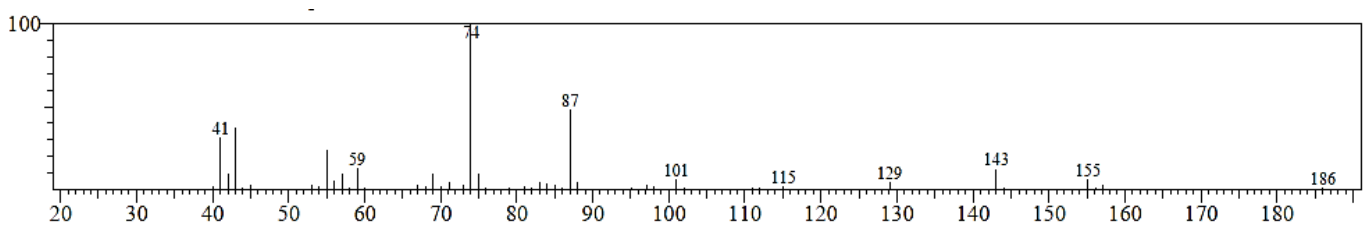

Sumber: (Penulis,2021)

Gambar 6: Peak 1 Spekta MS Rt $=15,118$

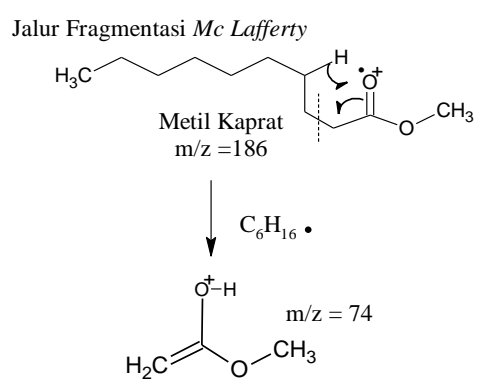

Jalur Fragmentasi 1

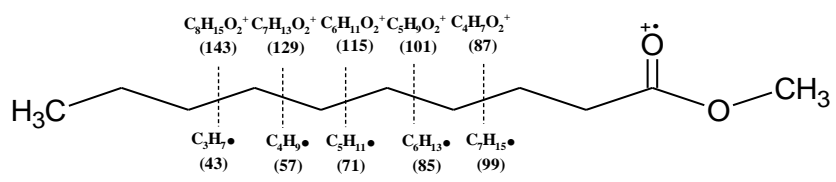

Deret ion $\mathrm{m} / \mathrm{z}=143,129,115,101,87$
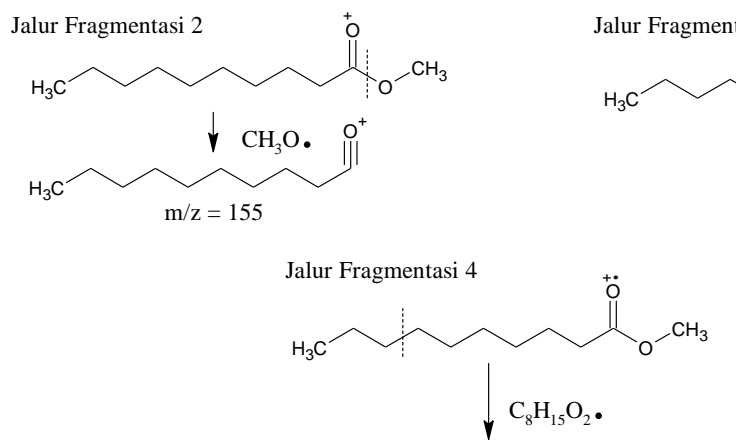

Jalur Fragmentasi 3<smiles>CCCCCCCCCC(=O)OC</smiles><smiles>COC=[O+]</smiles>

$\mathrm{m} / \mathrm{z}=59$

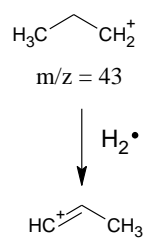

Deret ion $\mathrm{m} / \mathrm{z}=41$

Sumber: (Penulis, 2021)

Gambar 7: Mekanisme fragmentasi metil kaprat

Gambar 8 merupakan spetra massa komponen dari peak 2 dengan $\mathrm{Rt}=20,418$ menit memberikan puncak-puncak dengan m/z sebagai berikut: 214, 199, 183, 171, 157 ,
143, 129, 115, 101, 87, 74, 57, dan 41. Berdasarkan literatur data spektrum spetra massa menunjukkan bahwa komponen pada Rt $=20,418$ adalah senyawa metil laurat 
(metil dodekanoat). Mekanisme dari pola fragmentasi senyawa selengkapnya dapat dilihat pada Gambar 9.

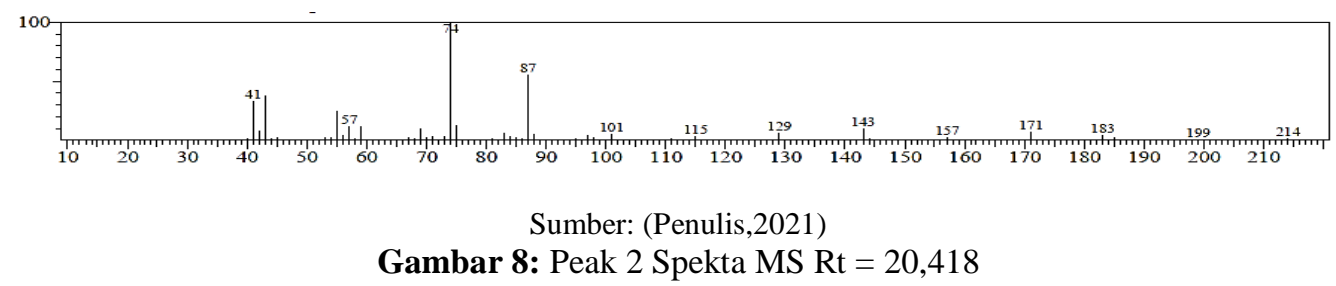

Jalur Fragmentasi Mc Lafferty
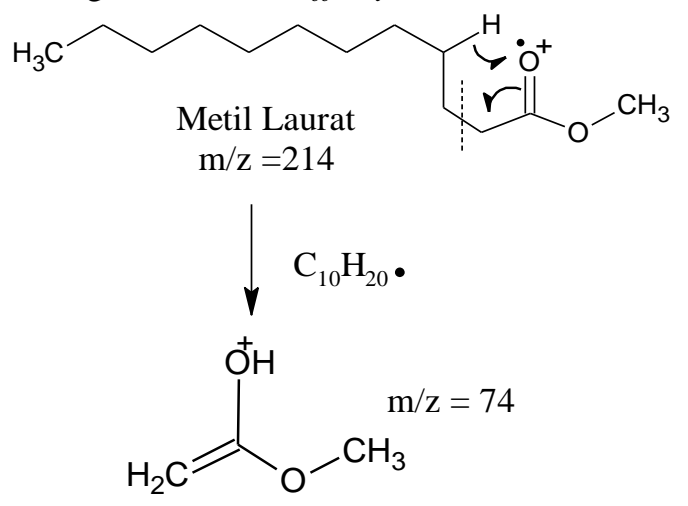

Jalur Fragmentasi 1

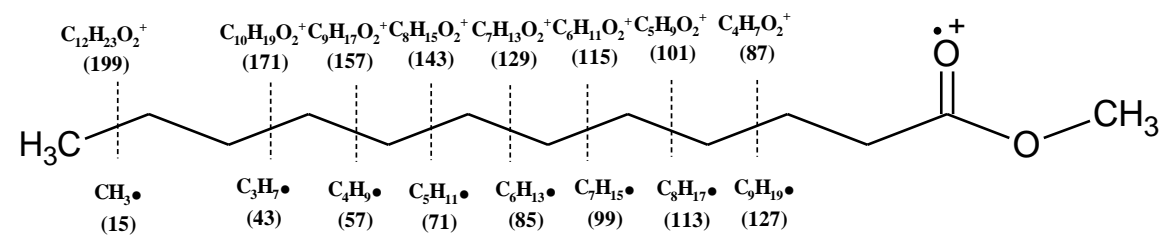

Deret ion $\mathrm{m} / \mathrm{z}=199,171,157,143,129,115,101,87$
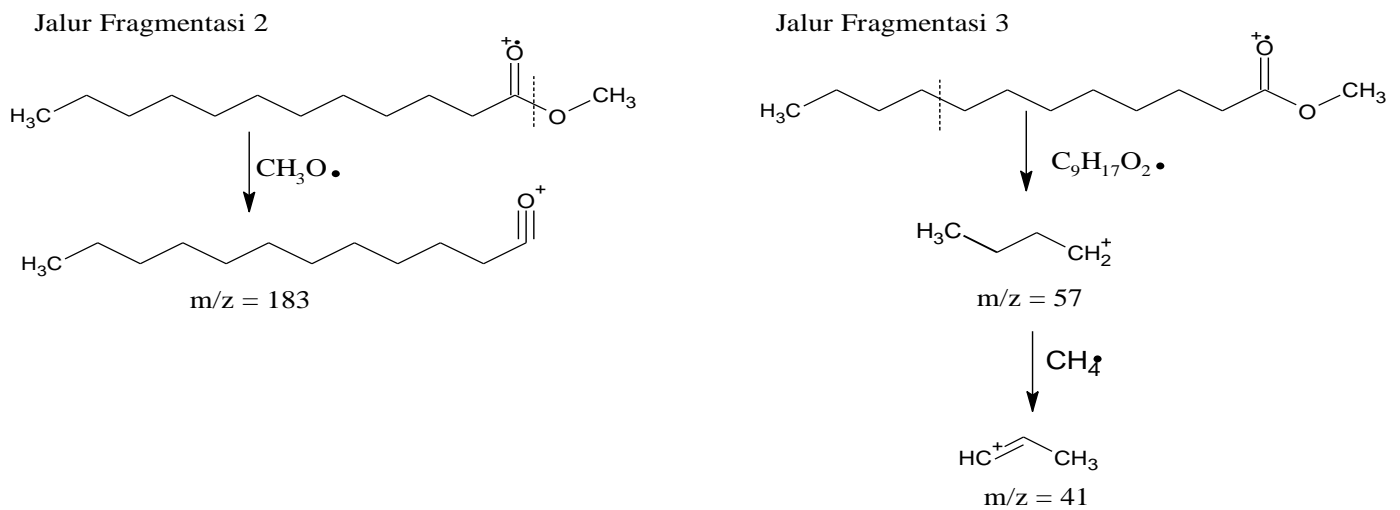

Sumber: (Penulis,2021)

Gambar 9: Mekanisme fragmentasi metil laurat

Gambar 10 merupakan spetra massa komponen peak 3 dengan $\mathrm{Rt}=20,684$ menit memberikan puncak-puncak dengan $\mathrm{m} / \mathrm{z}$ sebagai berikut: $214,183,171,157,143$, 129, 115, 101, 97, 87, 74, 59, dan 41. Berdasarkan literatur data spektrum spetra massa menunjukkan bahwa komponen pada $\mathrm{Rt}=20,684$ adalah senyawa metil laurat (metil dodekanoat). Mekanisme dari pola fragmentasi senyawa selengkapnya dapat dilihat pada Gambar 11. 


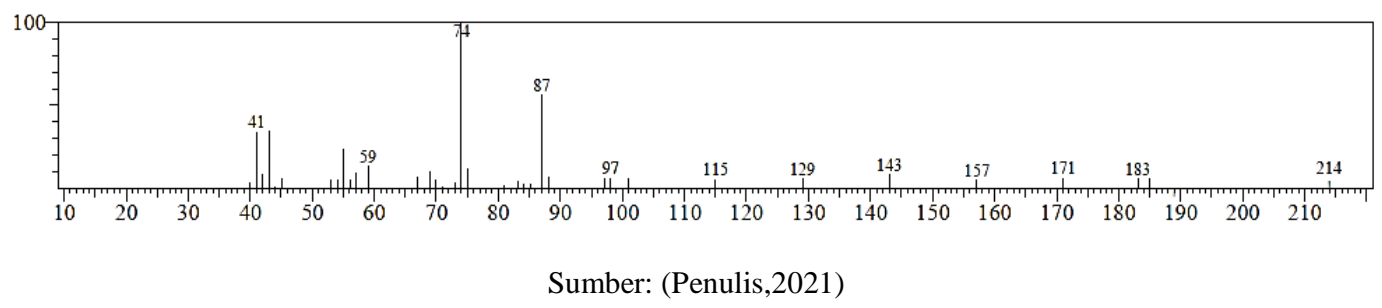

Gambar 10: Peak 3 Spekta MS Rt $=20,684$

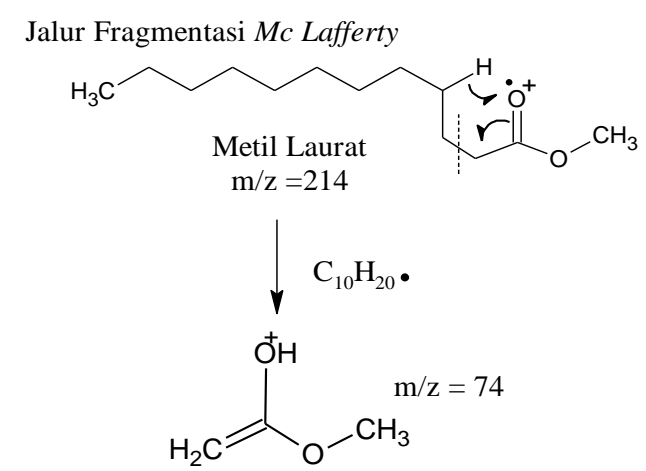

Jalur Fragmentasi 1

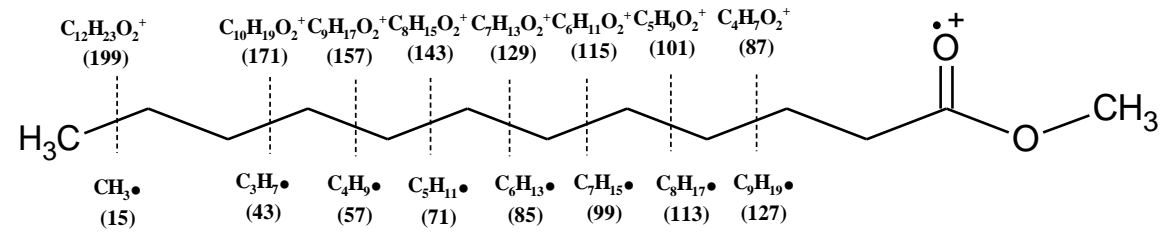

Deret ion $\mathrm{m} / \mathrm{z}=199,171,157,143,129,115,101,87$
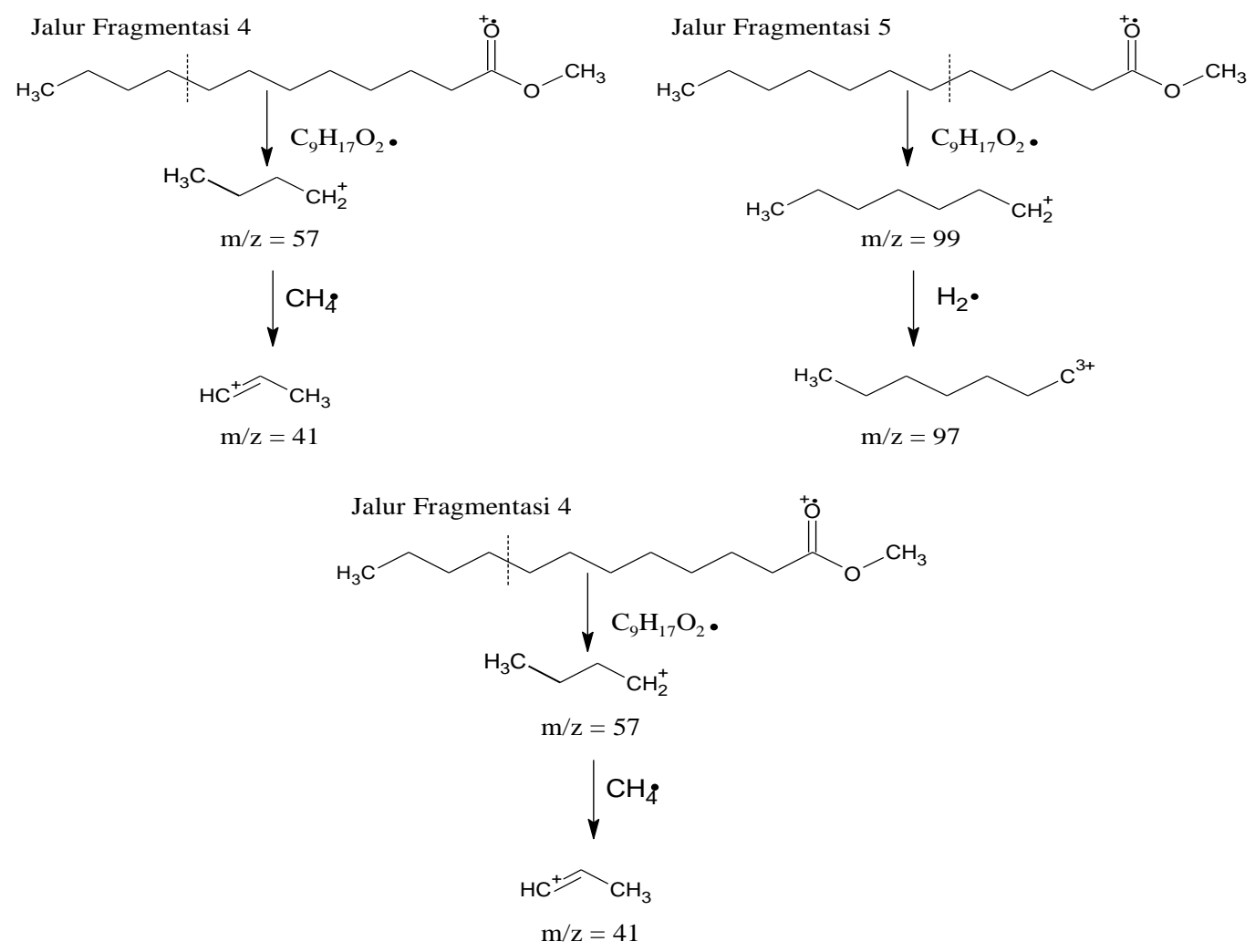

Sumber: (Penulis,2021)

Gambar 11: Mekanisme fragmentasi metil laurat 
Gambar 12 merupakan spetra massa komponen peak 4 dengan $\mathrm{Rt}=25,139$ menit memberikan puncak-puncak dengan $\mathrm{m} / \mathrm{z}$ sebagai berikut: $242,211,199,185,171$, 157, 143, 129, 115, 101, 87, 74, 57, dan 41 . Berdasarkan literatur data spektrum spetra massa menunjukkan bahwa komponen pada $\mathrm{Rt}=25,139$ adalah senyawa metil miristat (metil tetradekanoat). Mekanisme dari pola fragmentasi senyawa selengkapnya dapat dilihat pada Gambar 13.

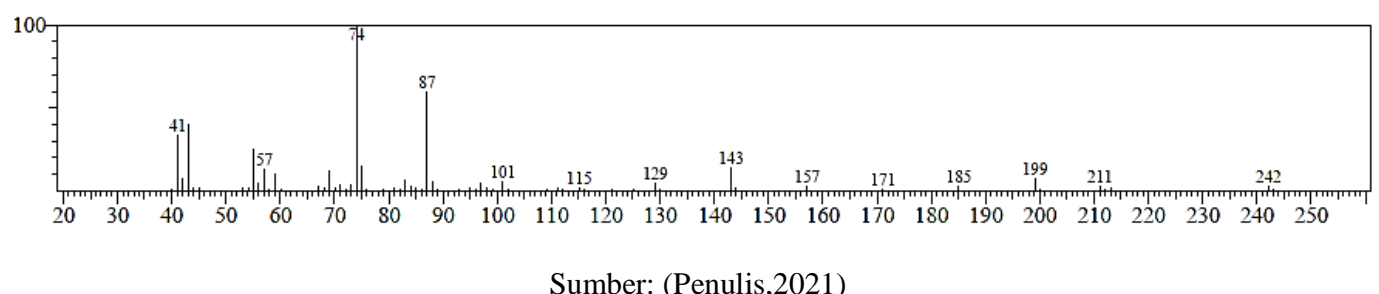

Gambar 12: Peak 4 Spekta MS Rt $=25,139$

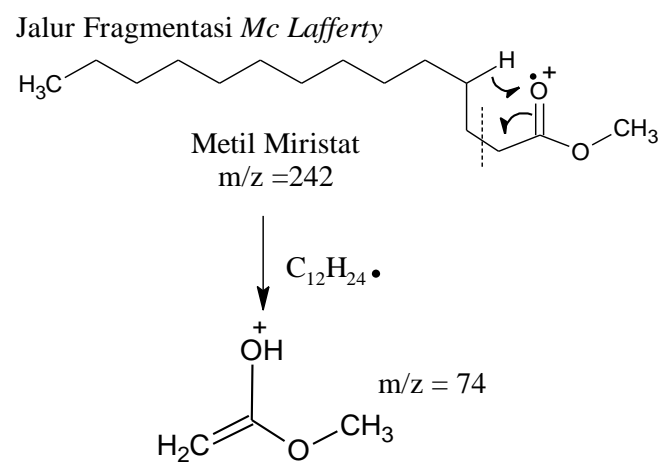

Jalur Fragmentasi 1

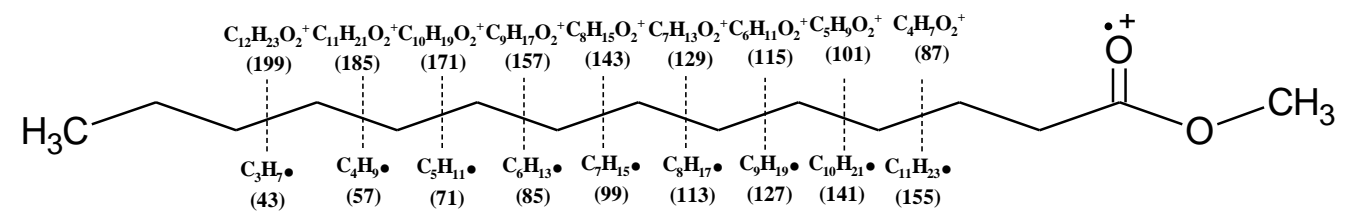

Deret ion $\mathrm{m} / \mathrm{z}=199,185,171,157,143,129,115,101,87$
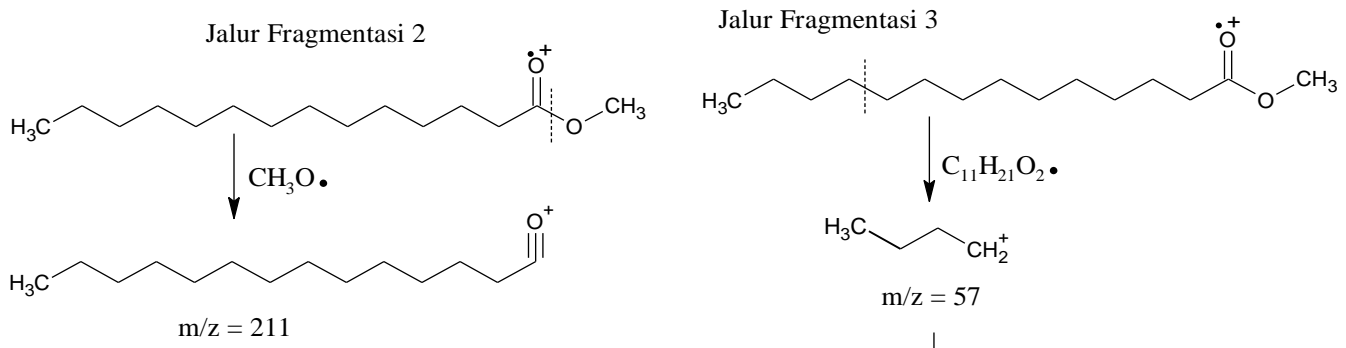

$\mathrm{m} / \mathrm{z}=57$

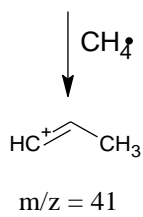

Sumber: (Penulis,2021)

Gambar 13: Mekanisme fragmentasi metil miristat

Gambar 14 merupakan spetra massa komponen peak 5 dengan $\mathrm{Rt}=29,427$ menit memberikan puncak-puncak dengan $\mathrm{m} / \mathrm{z}$ sebagai berikut: 270, 239, 227, 213, 199, $185,171,157,143,129,115,101,87,74,57$, dan 41. 
Berdasarkan literatur data spektrum Mekanisme dari pola fragmentasi senyawa spetra massa menunjukkan bahwa selengkapnya dapat dilihat pada Gambar 15. komponen pada $\mathrm{Rt}=29,427$ adalah senyawa metil palmitat (metil heksadekanoat).

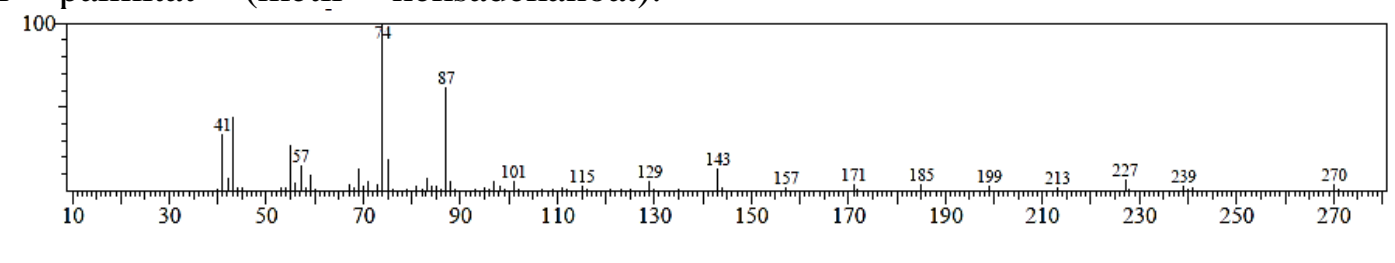

Sumber: (Penulis,2021)

Gambar 14: Peak 5 Spekta MS Rt $=29,427$

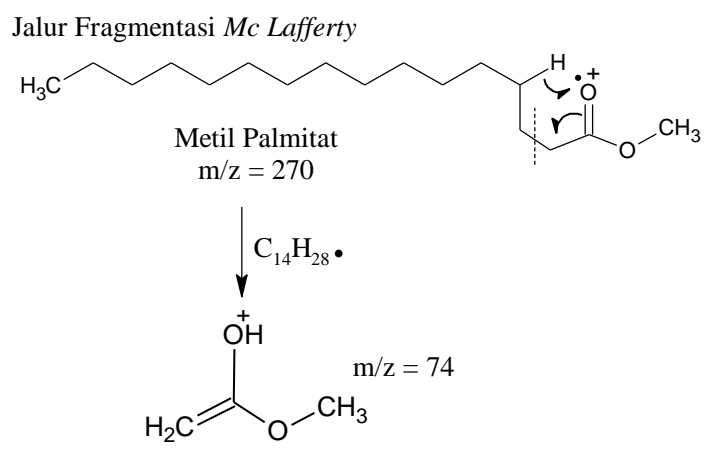

Jalur Fragmentasi 1

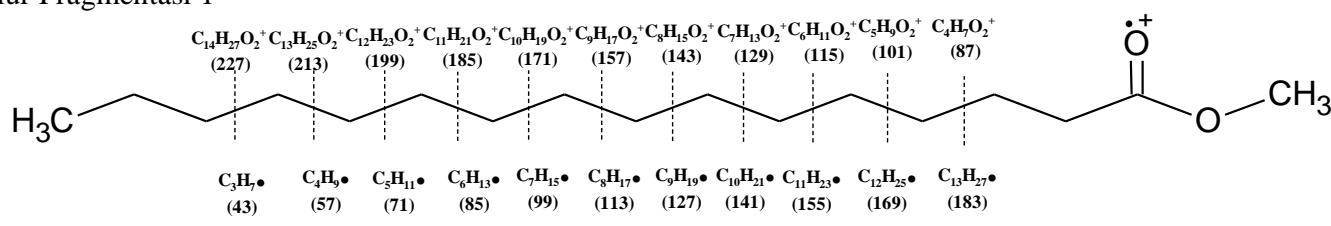

Deret ion $\mathrm{m} / \mathrm{z}=227,213,199,185,171,157,143,129,115,101,87$

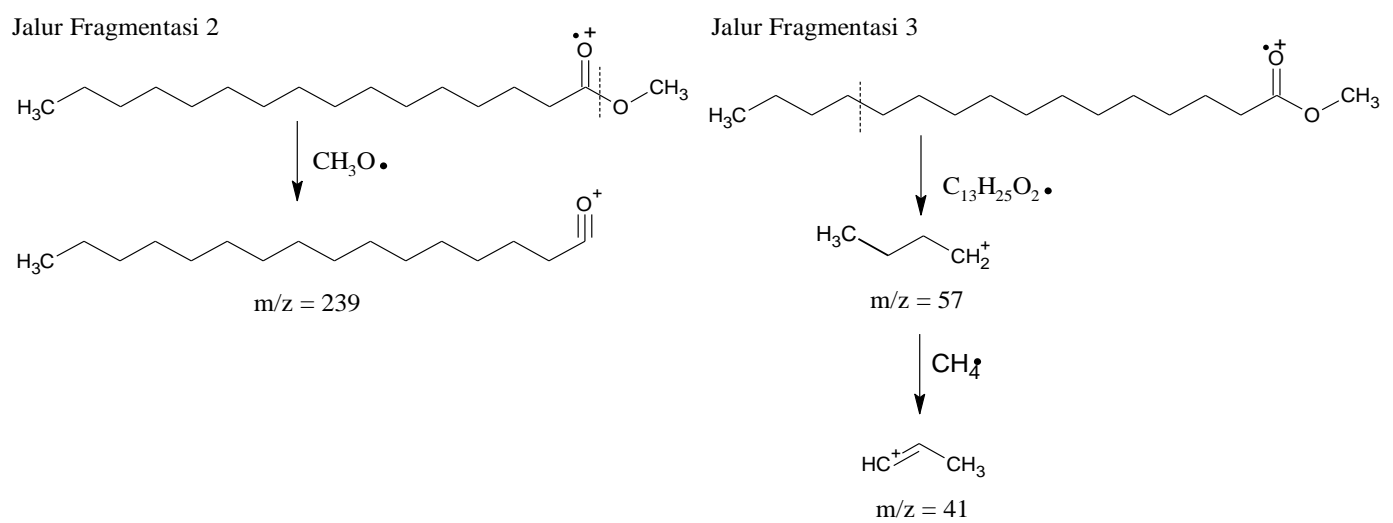

Sumber: (Penulis,2021)

Gambar 15: Mekanisme fragmentasi metil palmitat

Gambar 16 merupakan spetra massa komponen peak 6 dengan $\mathrm{Rt}=32,873$ menit memberikan puncak-puncak dengan $\mathrm{m} / \mathrm{z}$ sebagai berikut: 264, 222, 180, 166, 137, 123, 97, 83, 74, 69, 55, dan 41. Berdasarkan literatur data spektrum spetra massa menunjukkan bahwa komponen pada Rt = 32,873 adalah senyawa metil oleat (metil cis-9-oktadekanoat). Mekanisme dari pola fragmentasi senyawa selengkapnya dapat dilihat pada Gambar 17. 


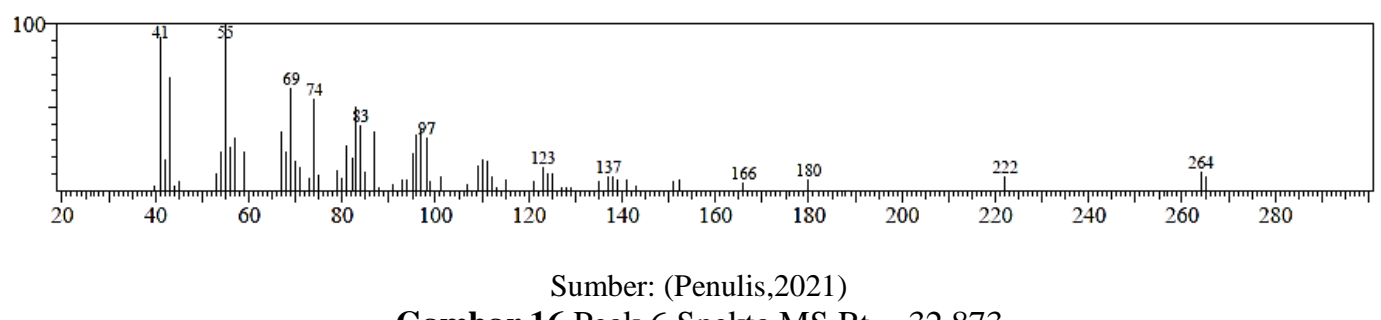

Gambar 16 Peak 6 Spekta MS Rt = 32,873
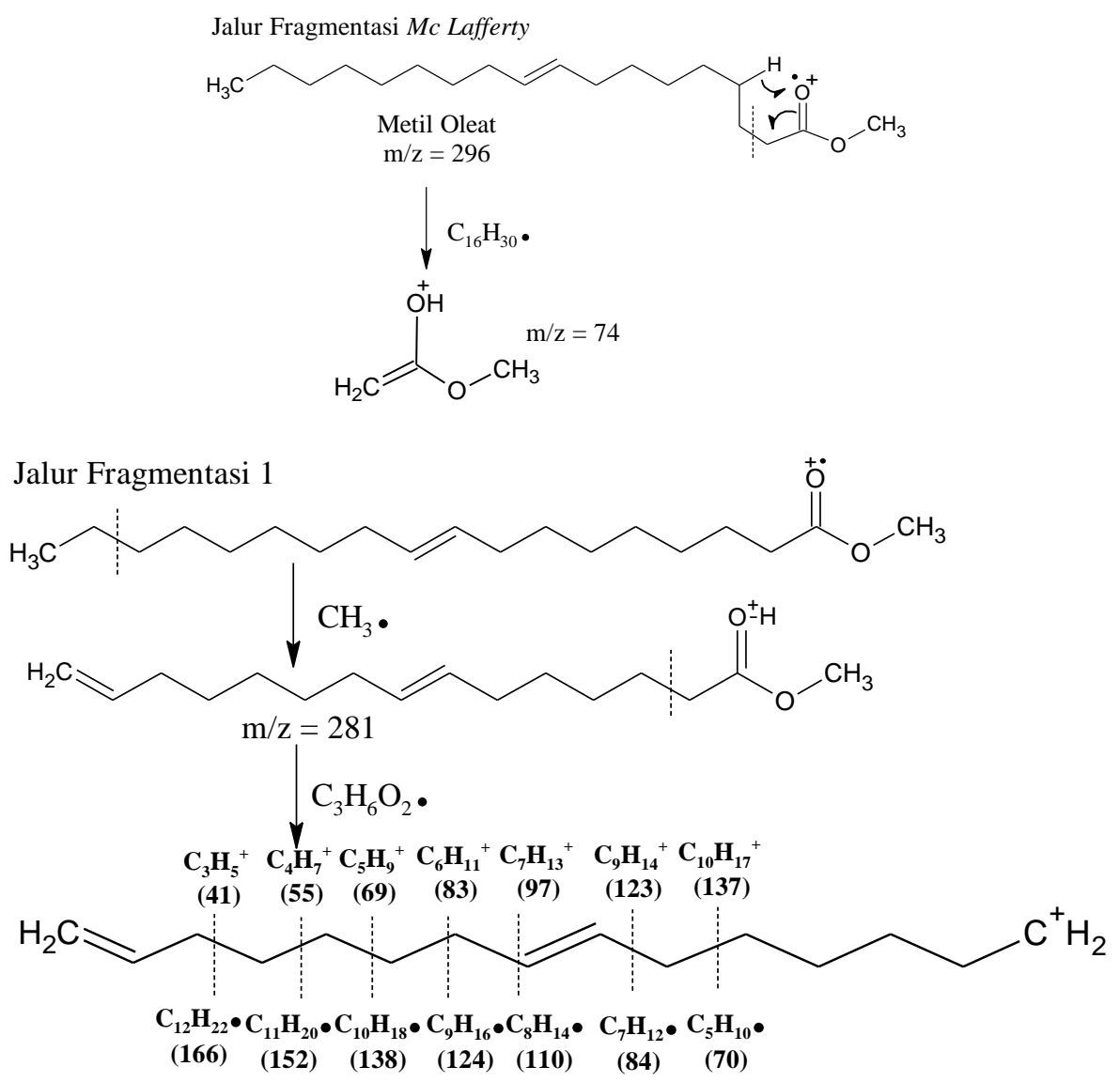

Deret ion $\mathrm{m} / \mathrm{z}=41,55,69,83,97,123,137$ 

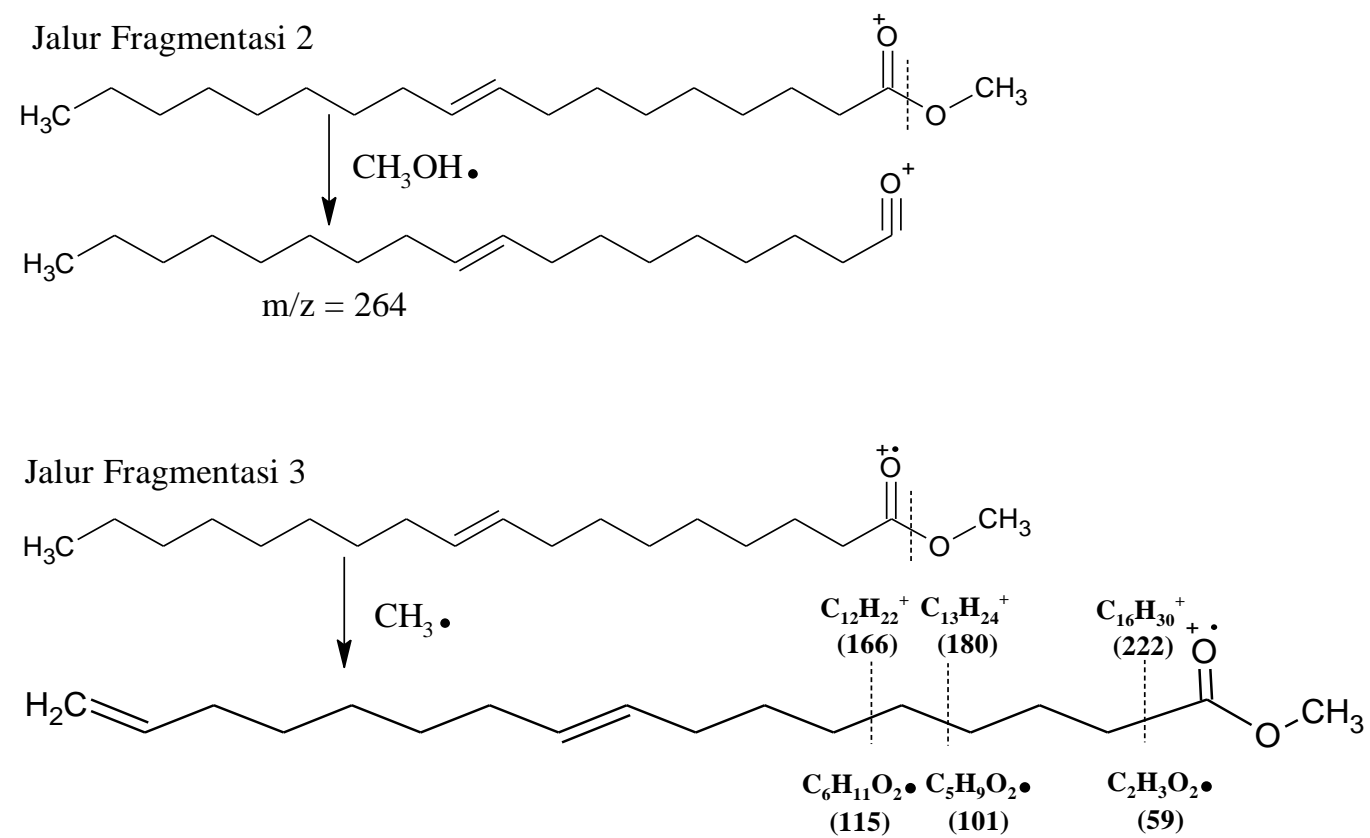

Deret ion $\mathrm{m} / \mathrm{z}=166,180,222$

Sumber: (Penulis,2021)

Gambar 17:Mekanisme fragmentasi metil oleat

Gambar 18 merupakan spetra massa komponen peak 7 dengan $\mathrm{Rt}=33,357$ menit memberikan puncak-puncak dengan $\mathrm{m} / \mathrm{z}$ sebagai berikut: 298, 255, 199, 143, 129, 101, 87, 74, 57, 43 dan 41. Berdasarkan literatur data spektrum spetra massa menunjukkan bahwa komponen pada Rt = 33,357 adalah senyawa metil stearat (metil oktadekanoat). Mekanisme dari pola fragmentasi senyawa selengkapnya dapat dilihat pada Gambar 19.

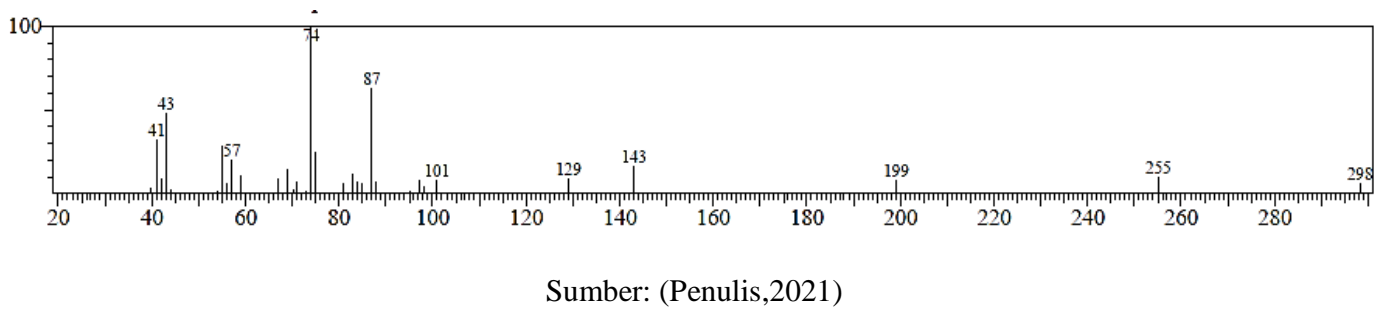

Gambar 18: Peak 7 Spekta MS Rt $=33,357$

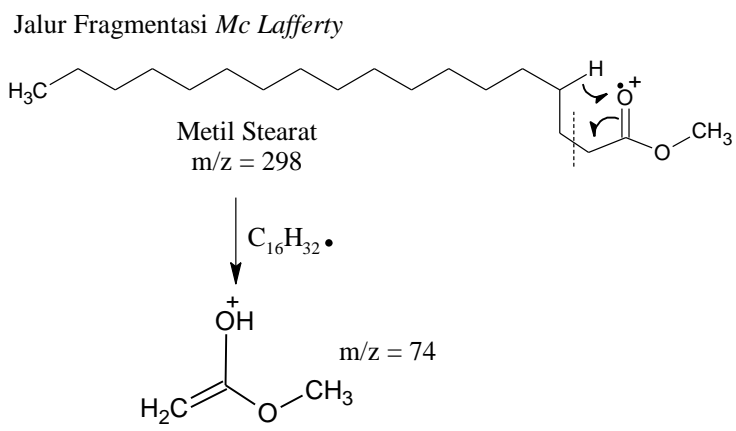


Jalur Fragmentasi 1

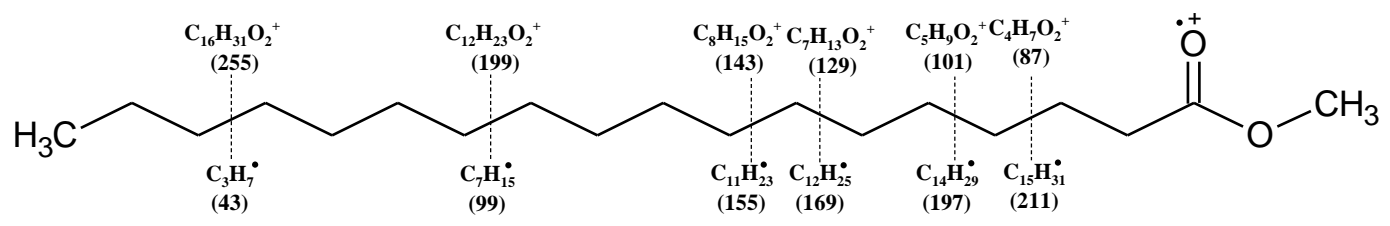

Deret ion $\mathrm{m} / \mathrm{z}=255,199,143,129,101,87$

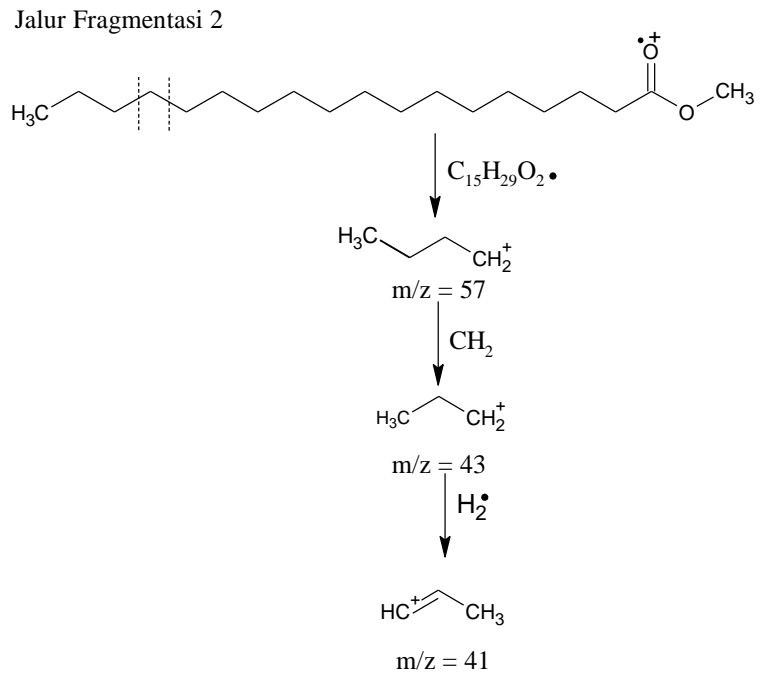

Sumber: (Penulis,2021)

Gambar 19 Mekanisme fragmentasi metil stearat

Spektra massa dari masing-masing komponen mengkonfirmasi bahwa ketujuh komponen merupakan senyawa metil ester.
Berikut data kandungan senyawa metil ester hasil analisis sampel.

Tabel 3 Komposisi Metil ester dari minyak kelapa

\begin{tabular}{|c|c|l|c|c|}
\hline Peak & Waktu Retensi & \multicolumn{1}{|c|}{ Nama } & BM(g/mol) & Area(\%) \\
\hline 1 & 15,118 & Metil Kaprat & 186 & 6,33 \\
\hline 2 & 20,418 & Metil Laurat & 214 & 63,26 \\
\hline 3 & 20,684 & Metil Laurat & 214 & 0,62 \\
\hline 4 & 25,139 & Metil Miristat & 242 & 20,4 \\
\hline 5 & 29,427 & Metil Palmitat & 270 & 6,83 \\
\hline 6 & 32,873 & Metil Oleat & 296 & 1,93 \\
\hline 7 & 33,357 & Metil Stearat & 298 & 0,64 \\
\hline
\end{tabular}

Sumber: (Penulis,2021)

Senyawa metil ester yang terdeteksi merupakan komponen-komponen utama khas turunan alkil ester dari masing-masing asam lemak minyak kelapa. Komponen utama yang mempunyai luas area paling tinggi merupakan senyawa meti laurat dimana minyak kelapa terdiri dari komponen penyusun utama yaitu asam laurat.

\section{Analisa Biodiesel}

1. Analisa densitas

Analisis densitas hasil biodiesel dari minyak kelapa memiliki densitas sebesar 
$859 \mathrm{~kg} / \mathrm{m} 3$. Parameter Standar Nasional Indonesia (SNI) untuk densitas biodiesel memiliki nilai kisaran $850-890 \mathrm{~kg} / \mathrm{m} 3$. Dari hasil tersebut di atas densitas biodiesel sudah memenuhi Standar Nasional Indonesia (SNI).

\section{Analisa viskositas kinematika}

Hasil Analisa biodiesel memiliki nilai viskositas kematik sebesar 11,6 mm2/s. Sedangkan parameter Standar Nasional Indonesia (SNI) untuk viskositas kematik biodiesel memiliki nilai kisaran antara 2,3 $6 \mathrm{~mm} 2 / \mathrm{s}$. Viskositas biodiesel yang tinggi dapat juga dipengaruhi oleh kandungan trigliserida yang tidak bereaksi dengan metanol, dan komposisi asam lemak penyusun metil ester serta kontaminasi gliserin pada metil ester (Bajpai dan Tyagi, 2006).

\section{Analisa angka setana}

Analisa biodiesel minyak kelapa mempunyai angka setana sebesar 55,7 sedangkan nilai angka setana untuk solar adalah sebesar 45. Hasil analisis angka setana biodiesel minyak kelapa sudah memenuhi Standar Nasional Indonesia (SNI) dimana bilangan setana suatu biodiesel bernilai minimal 51 .

\section{Analisa residu karbon}

Biodiesel dari minyak kelapa pada penelitian ini memiliki residu karbon sebesar $0,37 \%$. Nilai residu karbon dari hasil analisis biodiesel minyak kelapa hampir memenuhi Standar Nasional Indonesia (SNI) dimana nilai residu karbon biodiesel maksimal $0,3 \%$.

\section{KESIMPULAN}

Berdasarkan hasil analisa dan karakterisasi katalis $\mathrm{CaO}$ dari cangkang telur bebek dan biodiesel dari minyak kelapa, maka kesimpulan dari penelitian ini adalah sebagai berikut:

1. Suhu kalsinasi yang menghasilkan $\mathrm{CaO}$ dengan pengotor paling sedikit adalah kalsinasi pada suhu $900^{\circ} \mathrm{C}$, sedangkan pada suhu kalsinasi $700^{\circ} \mathrm{C}$ belum terbentuk $\mathrm{CaO}$, suhu kalsinasi $800^{\circ} \mathrm{C}$ $\mathrm{CaO}$ sudah terbentuk akan tetapi masih banyak mengandung $\mathrm{CaCO}_{3}$, suhu kalsinasi $1000^{\circ} \mathrm{C}$ terbentuk $\mathrm{CaO}$ akan tetapi kandungan $\mathrm{CaCO}_{3}$ dan $\mathrm{Ca}(\mathrm{OH})_{2}$ lebih banyak dibandingkan dengan suhu kalsinasi $900^{\circ} \mathrm{C}$.

2. Proses transesterifikasi menghasilkan yield sebesar 92,12\%. Kandungan metil ester dari minyak kelapa berdasarkan presentase area paling tinggi adalah metil laurat, metil miristat, metil palmitat, metil kaprat, metil oleat dan metil stearat.

3. Pengujian karakteristik biodiesel terhadap densitas, viskositas kinematik, angka setana, dan residu karbon menghasilkan nilai densitas $859 \mathrm{~kg} / \mathrm{m}^{3}$, viskositas kinematik $11,6 \mathrm{~mm}^{2} / \mathrm{s}$, angka setana 55,7 dan residu karbon $0,37 \%(\mathrm{~b} / \mathrm{b})$

\section{DAFTAR PUSTAKA}

Bajpai, D., Tyagi, V , K. (2006). Biodiesel: Source, production, composition, properties and its benefits. Journal of Oleo Science. 55 (10): 487-502

Correia, L, M, et al. (2014). Characterization Of Calcium Oxide Catalysts From Natural Sources AndTheir Application In TheTransesterification Of Sunflower Oil. Bioresource technology. 151 (1): 207-213

Chiristina, N., Edwin, S., Herman, H., dan Yohanes, K. (2012). Pembuatan Biodiesel Dari Minyak Nyamplung Dengan Menggunakan Katalis Berbasis Kalsium. Jurnal Ilmiah. Issn 1412-7350

Fadhilah ,R., Rizmahardian, A, K., Margarita, M I. (2015). Sintesis Hidroksiapatit dari Cangkang Kerang Ale-Ale (Meretrix Spp) Sebagai Material Graft Tulang. 
Jurnal Majalah Ilmiah Al Ribaath. 12 (1): 44-60

Huang, Y., Zheng, X., Yin, Z., Tao, F., Fang, B., dan Hou, K. (2007). Preparation of Nitrogen-Doped $\mathrm{Tio}_{2}$ Nanopartikel Catalys and Its Catalytic Activity Under Visible Light. Chin J Chem Eng. 15 (6): 802 807

Husin, H., et al. (2011). Green Fabrication of La-Doped $\mathrm{NataO}_{3} \mathrm{Via}_{2} \mathrm{O}_{2}$ Assisted Sol-Gel Route for Photocatalytic Hydrogen Production. Applied Catalysis B-environmental. 102 (12): 343-351.

Kouzu, M., dan Hidaka, J. (2012). Transesterification of Vegetable Oil into Biodiesel Catalyzed by $\mathrm{CaO}$ : a review. Journal Fuel 93 (1): 1-12

Lesbani ,A., Palita, T., Risfidian, M., dan Fahmariyanti. (2013). Preparation of Calcium Oxide from Achatina Fulica As Catalyst For Production of Biodiesel From Waste Cooking Oil. Indo. J. Chem. 13 (2):176 - 180

Mohadi ,R., Lesbani, A, dan Susie, Y. (2013). Preparasi dan Karakterisasi Kalsium Oksida $(\mathrm{CaO})$ dari Tulang Ayam. Jurnal Chemistry, 6 (2): 7680

Prastyo, H, S., Margaretha, Y, Y., Ayucitra, A, dan Ismadji S. (2011). Transesterifikasi Minyak Kelapa Sawit dengan Menggunakan Katalis Padat dari cangkang Keong mas (Pomacea sp.). Prosiding Seminar Nasional Fundamental dan Aplikasi Teknik Kimia, Institut Teknologi Bandung.
Ramos, M, J, D., dan Díaz ,H, J. (2011). Pathways for Quantitative Analysis by X-Ray Diffraction.Journal Mineralogy and Petrology. 73-92

Rahman, M, A. (2018). Valorization of harmful algae E. compressa for biodiesel production in presence of chicken waste derived catalyst. Journal Renewable Energy. 129(1): 132-140

Satria, P, D., dan Salahudin, M. (2016). Pembuatan Biodiesel dari Minyak Kelapa dengan Katalis $\mathrm{NaOH}$ Menggunakan Gelombang Mikro (Microwave) Secara Kontinyu. Jurnal Teknik ITS. 5 (1): 2337-3559

Singh, N, B., dan Singh, N, P. (2005). Formation Of Cao From Thermal Decomposition Of Calcium Carbonate In The Presence Of Carboxylic Acids. Journal Therm. 89(1):159-162

Stadelman, W, J. (2000). Eggs and egg products In Encyclopedia of Food Science and Technology second ed. New York: Jhon Wiley and Sons.

Wei, Z., Xu, C., Li, B. (2009). Application of Waste Eggshell As Low-Cost Solid Catalyst For Biodiesel Production. Bioresource Technology. 100(11):2883-2885

Zuhra., Husni, H., Fikri, H., Wahyu, R. (2015). Preparasi Katalis Abu Kulit Kerang Untuk Transesterifikasi Minyak Nyamplung Menjadi Biodiesel. Jurnal Agritech, 35(1):6977 
Bidang Lingkungan Binaan dan Rekayasa 